\title{
Correlation of Blood Lead Level with Blood Pressure Women of Childbearing Age in the Coastal Areas of North Semarang, Indonesia
}

\author{
Farah Khonsa Nabila, Sulistiyani Sulistiyani", Yusniar Hanani
}

\author{
Environmental Health Department, Public Health Faculty, Diponegoro University, Indonesia \\ *Corresponding author: sulistiyani@live.undip.ac.id
}

\begin{abstract}
The prevalence of non-communicable diseases has increased based on the results of the Basic Health Research (RISKESDAS) 2018 compared to the Basic Health Research (RISKESDAS) 2013. Hypertension was included in the top 10 diseases at the Bandarharjo community health center from 2016 to 2018. The purpose of this study was to determine the correlation of blood lead level with blood pressure women of childbearing age in the Coastal areas of the North Semarang, Indonesia. Sample 66 respondent were all women of childbearing age in that area. The research was analytic observational with crosssectional design. This study was conducted in the Sub-District of North Semarang. The result showed there was correlation between blood lead level with diastolic blood pressure, and there was correlation between BMI with systolic blood pressure and with diastolic blood pressure There were no correlation between blood lead level with systolic blood pressure, and no correlation between age with systolic and diastolic blood pressure, no correlation between sodium consumption with systolic and diastolic blood pressure.
\end{abstract}

Keywords—blood lead level, blood pressure, women of childbearing age.

\section{INTRODUCTION}

Basic Health Research Data (RISKESDAS) 2018 explains the prevalence of hypertension increase from $25.8 \%$ in 2013 to $34.1 \%$ in $2018 .^{1}$ Risk factors in hypertension are genetic factors, age, obesity, stress, high intake of sodium, exposure heavy metal etc. Environmental factors as the risk factor of hypertension such as exposure of heavy metal. Lead as a heavy metal exposure contributes to increased activity of angiotensin-converting enzyme (ACE) in the pathogenesis of hypertension. ${ }^{2}$ Lead intoxication illustrates one of the environmental cases in the world.3 In 2016, lead resulted in 540,000 deaths worldwide.3 Women are more vulnerable to the immunotoxin effects of lead. ${ }^{4}$

Lead causes increased production of reactive oxygen species (ROS). In relation to health, ROS functions with the implications of several diseases such as cancer, cardiovascular disease (including hypertension), neurological diseases. ${ }^{5}$ Based on the above background, hypertension entered into the top 10 diseases so the authors wanted to carry out this study to see the correlation of blood lead level with blood pressure in women of childbearing age in the coastal area of North Semarang.

\section{METHODS}

This research is an analytic observational using cross-sectional method. The sample in this study consisted of 66 women of childbearing age. The sampling technique used is purposive sampling. The data collected in this study include Semarang City Health Profile in 2018 about hypertension cases and the top 10 diseases in Bandarharjo Health Center hypertension cases. The independent variable in this study were the lead blood level, while the dependent variable blood pressure.

\section{RESULTS}

Table 1. Respondent Characteristic

\begin{tabular}{lccccc}
\hline \multicolumn{1}{c}{ Variable } & $\mathrm{f}$ & Min & Max & Mean & SD \\
\hline Age (years) & 66 & 15 & 55 & 29.42 & 8.4 \\
$\begin{array}{l}\text { Sistolik } \\
(\mathrm{mmHg})\end{array}$ & 66 & 81 & 162 & $\begin{array}{c}115.1 \\
4\end{array}$ & 13.9 \\
$\begin{array}{l}\text { Diastolic } \\
\text { (mmHg) }\end{array}$ & 66 & 62 & 98 & 77.73 & 8.6 \\
Blood lead & 66 & 45.5 & 99.7 & 75.9 & 12.7 \\
\hline
\end{tabular}




\begin{tabular}{lccccc} 
level $(\mu \mathrm{g} / \mathrm{dl})$ & & & & & 4 \\
BMI & 66 & 14.6 & 36.6 & 24.23 & 4.37 \\
$\begin{array}{l}\text { Sodium } \\
\begin{array}{l}\text { consumption } \\
\text { (mg/day) }\end{array}\end{array}$ & 66 & 256 & 1485. & 538.6 & 212. \\
\hline
\end{tabular}

Table 1 shows, the age of respondent mean 29.42 years; Blood lead level mean $75.9 \mu \mathrm{g} / \mathrm{dl}$. The standard of Blood lead level for adults from ACGIH 2017 was $20 \mu \mathrm{g} / \mathrm{dl}$, but for pregnancy woman from CDC 2010 and AOEC 2007 was $5 \mu \mathrm{g} / \mathrm{dl}$. BMI mean 24.23 and sodium consumption mean $538.6 \mathrm{mg}$.

Table 2. The Categories of Respondent Characteristic

\begin{tabular}{lcc}
\hline \multicolumn{1}{c}{ Characteristic } & $\mathrm{n}$ & $\%$ \\
\hline Systolic blood pressure & 43 & 65.2 \\
Normal & 19 & 28.8 \\
Pre-hypertension & 3 & 4.5 \\
Stage 1 hypertension & 1 & 1.5 \\
Stage 2 hypertension & & \\
Diastolic blood pressure & 40 & 60.6 \\
Normal & 20 & 30.3 \\
Pre-hypertension & 6 & 6 \\
Stage 1 hypertension & & \\
Blood lead level & 1 & 1.5 \\
30-50 $\mu$ g/dl & 69 & 98.5 \\
50-100 $\mu \mathrm{g} / \mathrm{dl}$ & & \\
BMI & 2 & 3 \\
Thin & 37 & 56.1 \\
Normal & 15 & 22.7 \\
Over weight & 12 & 18.2 \\
Obesity & & \\
\hline
\end{tabular}

Table 2. shows that women of childbearing age with normal systolic blood pressure $(65.2 \%)$, and with normal diastolic blood pressure $(60.6 \%)$. Respondents with blood lead levels $50-100 \mu \mathrm{g} / \mathrm{dl}$ was $98.5 \%$. Most of respondents did not have a history of hypertension $(66.7 \%)$. Most of respondent normal in BMI $(56.1 \%)$.
Table 3. Bivariate Analysis of Independent Variable with Dependent Variable Systolic Blood Pressure Using the Spearman Rank Correlation Test

\begin{tabular}{|c|c|c|c|}
\hline $\begin{array}{l}\text { Dependen } \\
\text { t Variable }\end{array}$ & $\begin{array}{l}\text { Dependent } \\
\text { Variable }\end{array}$ & $\mathrm{p}$ & Explanation \\
\hline $\begin{array}{l}\text { Systolic } \\
\text { Blood }\end{array}$ & $\begin{array}{ll}\text { Blood } & \text { Lead } \\
\text { level } & \end{array}$ & 0.496 & No correlation \\
\hline \multirow[t]{3}{*}{ Pressure } & Age & 0.194 & No correlation \\
\hline & $\begin{array}{l}\text { Sodium } \\
\text { consumption }\end{array}$ & 1.000 & No correlation \\
\hline & BMI & 0.024 & Correlation \\
\hline
\end{tabular}

There was correlation between blood lead level with systolic blood pressure

Table 4. Bivariate Analysis of Independent Variable with Dependent Variable Diastolic Blood Pressure Using the Spearman Rank Correlation Test

\begin{tabular}{|c|c|c|c|}
\hline $\begin{array}{c}\text { Dependent } \\
\text { Variable }\end{array}$ & $\begin{array}{l}\text { Dependent } \\
\text { Variable }\end{array}$ & $\mathrm{p}$ & Explanation \\
\hline $\begin{array}{c}\text { Diastolic } \\
\text { Blood }\end{array}$ & $\begin{array}{l}\text { Blood Lead } \\
\text { level }\end{array}$ & 0.037 & Correlation \\
\hline \multirow[t]{3}{*}{ Pressure } & Age & 0.099 & No correlation \\
\hline & $\begin{array}{l}\text { Sodium } \\
\text { consumption }\end{array}$ & 1.000 & No correlation \\
\hline & BMI & 0.016 & Correlation \\
\hline
\end{tabular}

There were correlation between blood lead level with diastolic blood pressure and between BMI with diastolic blood pressure.

\section{DISCUSSION}

\section{Correlation of Lead Blood Level with Blood Pressure}

Most of respondents have highest blood lead levels $(50-100 \mu \mathrm{g} / \mathrm{dl})$, there were $98.5 \%$ respondents, and the mean of blood lead level was $75.9 \mu \mathrm{g} / \mathrm{dl}$. Respondent with normal Systolic blood pressure $65.2 \%$, and normal diastolic blood pressure $60.6 \%$. Based on the Spearman rank correlation test results with significance value of 0.496 (> 0.05) meaning that there was no correlation between blood lead level with systolic blood pressure.

There was no correlation between blood lead level with systolic blood pressure $(p=0.496, p>0.05)$ because the lead have no effect to increase the systolic blood pressure. Measurement of lead content in seawater is 0.466 ppm which seawater consists of biota such as fish. There are several types of fish in seawater and the possibility of 
fish consumed by the local population contains lead because the results of seawater measurements are above the threshold value res, and there were high blood lead levels in the most of respondent. The effects of high blood lead levels do not affect blood pressure. Because the metabolic process of lead in the blood in each person is different.

Based on the Spearman rank correlation test results obtained significance value of $0.037(<0.05)$ means that was correlation between diastolic blood pressure with lead blood level. There was correlation because lead exposure interferes with the work of nitric oxide (NO) which functions to widen the arteries and regulate blood pressure. As a result, the pulmonary vein becomes narrow in diameter, causing an increase in pressure when blood enters the heart during relaxation in the diastolic phase which then triggers an increase in blood pressure in the diastolic phase. ${ }^{6}$

\section{Correlation Between Age and Blood Pressure}

In this study, that the age of most respondents 29.42 years. Based on the Spearman rank correlation test results obtained a significance value of 0.194 (> 0.05) meaning that there was no correlation between age and systolic blood pressure. There was no correlation between age and diastolic blood pressure, the significance value $0.099(>0.05)$.

However, age is susceptible to an increase in high blood pressure at the age of $>45$ years. Because at this age the elasticity of the arteries begins to decrease, becoming more susceptible to high blood pressure.

\section{Correlation of Sodium Consumption with Blood Pressure}

In the study, that most respondents consume enough sodium $(95.5 \%)$, p-value $=1,000(>0.05)$ meaning that there was no correlation between sodium consumption with blood pressure. One of the factors that can affect blood pressure is high sodium intake. There was no correlation between sodium intake with systolic or diastolic blood pressure is possible because most of all respondents (95.5\%) consume enough sodium.

\section{Correlation of Body Mass Index (BMI) with Blood Pressure}

In the study, that the most BMI of respondents were normal $(56.1 \%)$. Spearman rank correlation test results obtained a significance value of $0.024 \quad(<0.05)$ means that there is a correlation between BMI with systolic blood pressure. It also obtained a significance value of $0.016(<0.05)$ meaning that there was correlatiom between BMI with diastolic blood pressure.
There was a correlation between BMI with blood pressure is possible because of more respondents have normal categories of BMI $(74.2 \%)$ and more normal blood pressure respondents $(56.1 \%)$. An increase in blood pressure is in line with an increase in BMI. The normal BMI categories reflects the condition of healthy blood vessels without fat and cholesterol buildup so there is no increase in blood pressure

\section{CONCLUSION}

This study concludes that: 1) There was correlation between blood lead levels with diastolic blood pressure; there was correlation between BMI with systolic blood pressure; and there was correlation between BMI with diastolic blood pressure. 2) There was no correlation between blood lead levels with systolic blood pressure, no correlation between age with systolic and diastolic blood pressure; no correlation between consumption of sodium with systolic and diastolic blood pressure.

\section{REFERENCES}

[1] Ministry of Health of the Republic of Indonesia. Main Results Indonesian Health Research 2018. Jakarta: Health Research and Development Agency Ministry of Health Republic of Indonesia

[2] Mutasir, Setiani O, Sulistyani. 2016. The Correlation of Lead Blood Level with Blood Pressure on Labor in Car Body in Semarang. Indonesian Environmental Health Journal 15 (1); 14-21.

[3] World Health Organization (WHO). 2010. Childhood Lead Poisoning. Switzerland; WHO Press. 2010.

[4] Kumar S. Occupational and Environmental Exposure to Lead and Reproductive Health Impairment. 2018. Indian Journal of Occupational and Environmental Medicine. Vol 22 (3); 18-137.

[5] Laila NN, Shofwati. 2013. Lead Blood Level and Health Complaints in Gas Station Female Operators. Journal of Reproduction 4 (1): 41-49.

[6] Liliek W. The Correlation between Lead Blood Level and Blood Pressure in Consumers of Totok Shellfish (Polymesoda Erosa). 2017. Al-Irsyad Health Journal (JKA). Vol X, No.1.

[7] Ministry of Health Republic of Indonesia. Regulation of the Minister of Health of the Republic of Indonesia Number 28 of 2019 Concerning the Management of Nutrition Problems for Children Due to Diseases. 2019: 6-12

[8] Sase FA, Pramono A. The Correlation Between Physical Activity and Sodium Intake with Blood Pressure in Menopausal Women. Journal of Nutition College 2 (2). 2013.

[9] Gemala, Mega. Effect of Newspaper Use on Lead Content $(\mathrm{Pb})$ in Fried Foods. 2018. Journal of Engineering Ibn Sina 3 (1). 